\title{
Plasmablastic Lymphoma of the Maxillary Sinus Causing Orbital Complication
}

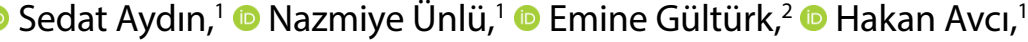 \\ (1) Nagehan Özdemir Barışık, ${ }^{3}$ ํ Begüm Başlı ${ }^{3}$
}

\author{
'Department of Otolaryngology, \\ Heath Sciences University Karta \\ Dr. Lütfi Kırdar Training and \\ Research Hospital, İstanbul, Turkey \\ ${ }^{2}$ Department of Hematology, Heath \\ Sciences University Karta \\ Dr. Lütfi Kırdar Training and \\ Research Hospital, İstanbul, Turkey \\ ${ }^{3}$ Department of Pathology, Heath \\ Sciences University Kartal \\ Dr. Lütfi Kırdar Training and \\ Research Hospital, İstanbul, Turkey \\ Submitted: 10.12.2017 \\ Accepted: 28.12.2016
}

Correspondence: Sedat Aydın, SBÜ Kartal Dr. Lütfi Kırdar Eğitim ve Araştırma Hastanesi KBB Kliniği, İstanbul, Turkey

E-mail: sedataydin63@yahoo.com

arysa

Keywords: Complication;

HICV-negative; maxillary sinus; nasal obstruction; orbita; plasmablastic lymphoma.

\begin{abstract}
Plasmablastic lymphoma (PBL) is a rarely seen diffuse large B cell lymphoma variant associated with acquired immunodeficiency syndrome, oral mucosa localization, and a poor prognosis. There is not yet a standard protocol for the treatment of PBL; the treatment of a small number of human immunodeficiency virus (HIV)-negative cases has been reported in case reports and series and shared on a case-by-case basis. Presently described is the case of a 60-year-old man with PBL that originated in the sinus and spread to the orbit. The patient was HIV-negative and immunocompetent. The treatment and follow-up are presented in the context of the available literature.
\end{abstract}

\section{INTRODUCTION}

Plasmablastic lymphoma (PBL) is characterized by excessive proliferation of cells that morphologically resemble immunoblasts and antigenically demonstrate a plasma cell phenotype. It is also a rare subtype of large B cell lymphomas with poor prognosis. The male-to-female ratio in PBL is I.9:I, which may be seen in HIV-negative cases, although it is usually extranodal in HIV-positive cases. ${ }^{[1,2]}$ Symptoms of B cell lymphomas are seen in $33 \%$ of HIVpositive and $50 \%$ in HIV-negative cases. In addition, the $\mathrm{Ki}-67$ index is usually $>90 \%$. Epstein-Barr virus-encoded RNA (EBER) positivity supports PBL. Chemotherapy is administered as the initial treatment. The most important factor affecting the prognosis is the amount of response given to chemotherapy, and the average life span for untreated patients is 3 months. ${ }^{[3,4]}$

\section{CASE REPORT}

A 60-year-old male patient presented to our clinic with nasal obstruction on the right side, frontal growth in the right eye, blurred vision, and impaired balance. The patient's father and uncle had lung cancer, and two brothers had passed away due to colon cancer. Proptosis in the right eye, limitation in inward gaze, and decrease in visual acuity were observed. 
The pupils were isochoric. Direct light reflex was negative in the right eye and positive in the left eye, whereas indirect light reflex was positive in the right eye and negative in the left eye. On nasal endoscopic examination, septum deviation in the right nasal cavity and posterior to the nasal septum a pale-colored mass with lobular contours, which completely filled the nasal cavity and whose source could not be clearly defined, were observed. There was lymphadenopathy of approximately $\mathrm{I} \mathrm{cm}$ in size in the right submandibular region that was painless on palpation.

The patient's hematological values were remarkable. They were as follows: white blood cell $9300 / \mathrm{mm}^{3}$, hemoglobin $13.6 \mathrm{~g} / \mathrm{dL}$, platelets $257,000 / \mathrm{mm}^{3}$, sedimentation rate 30 $\mathrm{mm} / \mathrm{h}$, and C-reactive protein II,5 $\mathrm{md} / \mathrm{L}$. Other biochemical test results were within normal limits, and serology tests for $\mathrm{HbsAg}$, anti-HBs, anti-HCV, and anti-HIV were negative.

A nasal mass with a diameter of $75 \times 28 \mathrm{~mm}$ disrupted the integrity of the medial wall of the right orbita was observed on paranasal sinus computed tomography (CT) and this lesion completely filled the maxillary, ethmoid sinuses and nasal cavity and also partially the right half of the frontal sinus extending into the sphenoid sinuses on facial magnetic resonance imaging (MRI) (Fig. la and b).

Informed consent was obtained from the patient. On endoscopic examination, under general anesthesia, we en- countered a pale, lobular, fragile, and hemorrhagic mass affecting the middle concha in the right nasal cavity that invaded the lamina papyracea, orbit, and paranasal sinuses. The mass was excised so as to ensure nasal respiration of the patient.

Histopathological sections showed diffuse proliferation, pleomorphic large hyperchromatic nuclei with prominent nucleoli, and large cells with eosinophilic cytoplasm. Infiltrating cells were CD38 and CDI38-positive, whereas CD20, CD56, and CD3 were negative, and EBER was positive. $\mathrm{Ki}-67$ proliferative indexes were $>90 \%$. Owing to the findings, the present case was interpreted as PBL (Fig. Ic-f).

Patient underwent positron emission tomography (PET)CT after consultation with the hematology clinic. PET-CT revealed intensely hypermetabolic (SUDmax: 21.0) spaceoccupying lesion measuring approximately $30 \times 40 \times 50 \mathrm{~mm}$ of primary malignant involvement that completely obliterated the frontal sinus and right ethmoid sinus and partially the right maxillary sinus and a moderately hypermetabolic lymph node (SUDmax: 5.5) measuring approximately 8 $\mathrm{mm}$ in diameter in the right submandibular lymphatic loge, suggesting the involvement of primary disease.

At 28-day intervals, 6 cycles of chemotherapy regimen using the EPOCH protocol (dose-increasing etoposide, vincristine, doxorubicin, cyclophosphamide, and prednisolone) were administered by the hematology clinic to
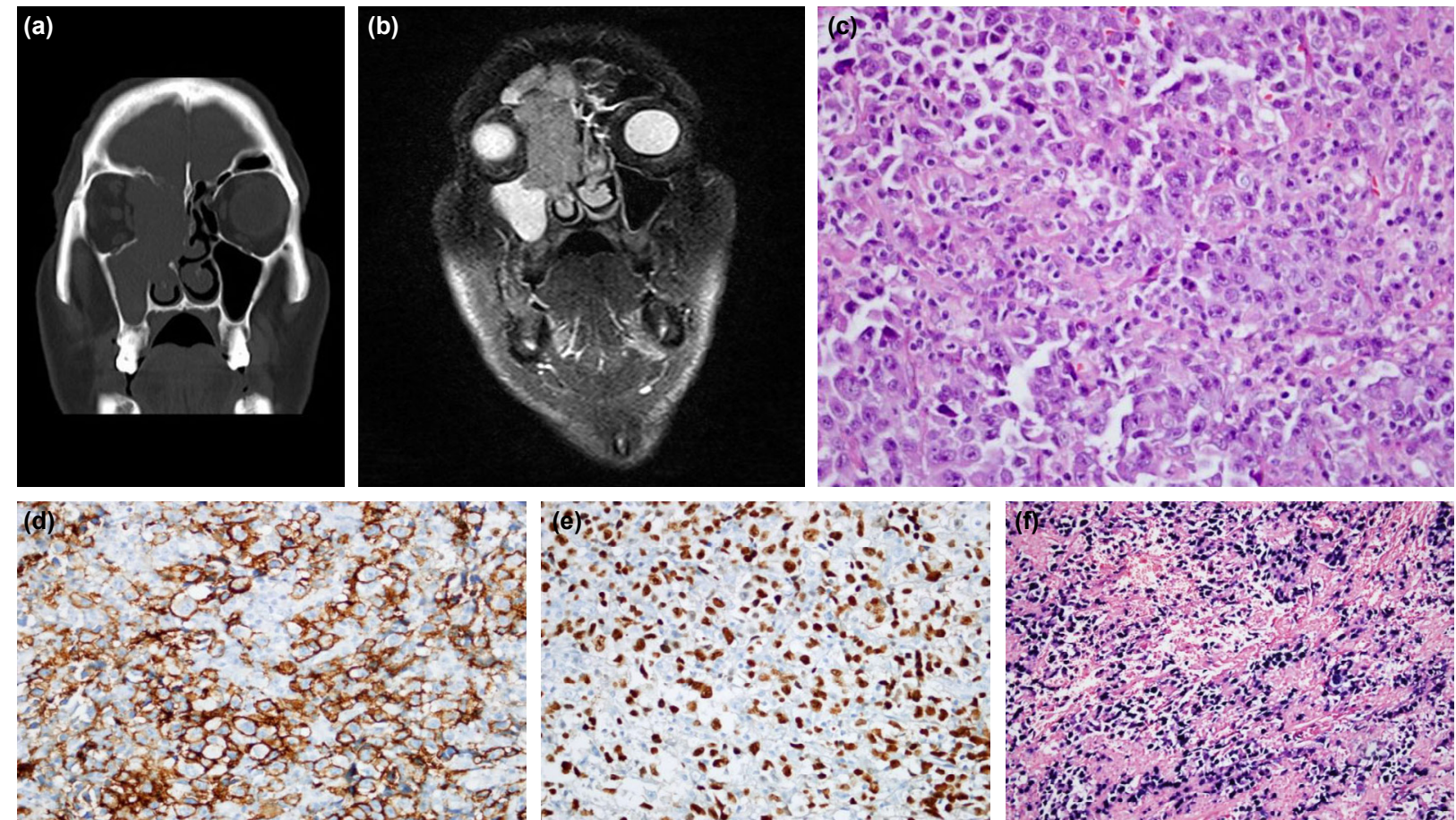

Figure 1. (a) Coronal section of paranasal sinus CT shows invasion of the mass stemming from the maxillary sinus into orbit and other sinuses. (b) On the facial MRI T1 coronal section, diffuse invasion of the mass into the right nasal passages, maxillary sinuses, orbits, and other sinuses is observed. (c) Histopathological appearance of plasmablastic lymphoma is stained with hematoxylin and eosin (×40). (d) Histopathologically, CD138 positivity of the plasmablastic lymphoma is observed ( $\times 40)$. (e) Immunohistochemical staining with $\mathrm{Ki}-67$, high proliferative index (×40). (f) Histopathologically, EBER has been shown to have an in situ hybridization positivity. 
the patient who did not demonstrate any evidence for involvement of lymphoma in the bone marrow biopsy specimen. In addition, intrathecal methotrexate therapy was applied for central nervous system prophylaxis. When the patient was evaluated I month after chemotherapy, proptosis of the right eye and limitation of inward gaze proceeded. At the control visit after 3 months, face MRI demonstrated considerable regression of the lesion, and face MRI and PET-CT showed complete response after 6 months. The patient under our surveillance is currently in remission for 2 years without recurrence.

\section{DISCUSSION}

PBL is a rare, rapidly progressive form of diffuse large B cell lymphomas and is often observed with jaw and oral mucosal involvement in HIV-positive cases. A small part of cases consist of HIV-negative cases, patients under immunosuppressive treatment after tissue-organ transplantation, patients with congenital immunosuppression, and patients with advanced age. It is especially important that PBL is shared on a case-by-case basis, as it is seen even more rarely in immunocompetent patients. ${ }^{[2]}$

PBL should be considered in the differential diagnosis of benign (nasal polyposis, mucus retention cysts, sinonasal papillomas, and juvenile nasopharyngeal angiofibromas) and malignant (epidermoid carcinoma, adenoid cystic carcinoma and adenocarcinoma, lymphoma, melanoma, esthesioneuroblastoma, undifferentiated carcinoma, sarcoma, and plasmacytoma) pathologies originating from the paranasal sinuses.

We should often think of malignant pathologies in the presence of symptoms and signs of nasal obstruction, pain, history of epistaxis, malodorous bloody nasal discharge, cheek swelling, diplopia, proptosis, malformations, and loss of maxillary teeth. On the other hand, in these cases, we encounter radiological evidence of invasion in the sinuses as opacification, softening of the surrounding structures, and erosion in the bone tissues. ${ }^{[5]}$

It was determined that the majority of the above symptoms and signs were present in our patient, and also the integrity of the medial wall of the right orbita was disrupted as revealed in radiological imaging. Histopathologically, diffuse large B cell lymphoma, PBL, and plasmablastic myeloma were considered in the differential diagnosis.

The absence of CD20 positivity excluded the possible diagnosis of diffuse large $B$ cell lymphoma. Detection of EBERpositive tumor cells, high Ki-67 proliferation index, CD56 negativity, and absence of bone marrow involvement also ruled out the diagnosis of anaplastic plasmacytoma.

In the meta-analysis of many case reports and studies, an increased incidence of PBL in the nasal cavity and sinus, gastrointestinal tract, skin, and lymph nodes in HIV-negative individuals has been reported. ${ }^{[6-9]}$ The majority of the cases were stage 4 , followed by stage I disease. As in our case, bone marrow involvement is rare. ${ }^{[10-13]} \mathrm{EB}$ virus infection is present in $74 \%$ of the cases, and there is no standard chemotherapy regimen currently accepted for PBL. [5,9,14] Although in patients with extranodal involvement the median survival is $<1$ year, our patient is in remission and is followed up by the hematology clinic for 2 years without disease recurrence.

In conclusion, PBL is a rare, rapidly progressive variant of diffuse large B cell lymphomas. Until treatment becomes standardized, the selection and outcome of the chemotherapy protocol will vary based on individual cases. Orbital involvement secondary to primary sinus lymphoma is rare, but it is possible that the clinician will discern these rarely seen cases after the evaluation of the clinical signs and symptoms specific to non-Hodgkin lymphoma together with the nasal cavity mass.

\section{Informed Consent}

Written informed consent was obtained from the patient for the publication of the case report and the accompanying images.

Peer-review

Internally peer-re viewed.

Authorship Contributions

Concept: S.A., N.Ü.; Design: S.A., H.A., E.G.; Data collection \&/or processing: N.Ü., B.B., H.A.; Analysis and/or interpretation: S.A., N.Ö.B., N.Ü., E.G.; Literature search: S.A.; Writing: S.A., E.G.; Critical review: S.A., E.G.

Conflict of Interest

None declared.

\section{REFERENCES}

1. Delecluse HJ, Anagnostopoulos I, Dallenbach F, Hummel M, Marafioti T, Schneider U, et al. Plasmablastic lymphomas of the oral cavity: a new entity associated with the human immunodeficiency virus infection. Blood 1997;89:1413-20.

2. Liu JJ, Zhang L, Ayala E, Field T, Ochoa-Bayona JL, Perez L, et al. Human immunodeficiency virus (HIV)-negative plasmablastic lymphoma: a single institutional experience and literature review. Leuk Res 2011;35:1571-7. [CrossRef]

3. Folk GS, Abbondanzo SL, Childers EL, Foss RD. Plasmablastic lymphoma: a clinicopathologic correlation. Ann Diagn Pathol 2006;10:8-12. [CrossRef]

4. Ak1 H, Difüz Büyük B Hücreli Lenfoma Patolojisi. Klinisyen-Patolog Ortak Lenfoma Kursu 2004;63-75.

5. Citardi MJ, Batra PS. The nose and paranasal sinuses. In: Lee KJ. Essential otolaryngology: head \& neck surgery. 9th ed. New York: McGraw-Hill; 2008. p. 365-412.

6. Scheper MA, Nikitakis NG, Fernandes R, Gocke CD, Ord RA, Sauk JJ. Oral plasmablastic lymphoma in an HIV-negative patient: a case 
report and review of the literature. Oral Surg Oral Med Oral Pathol Oral Radiol Endod 2005;100:198-206. [CrossRef]

7. Saraceni C, Agostino N, Cornfield DB, Gupta R. Plasmablastic lymphoma of the maxillary sinus in an HIV-negative patient: a case report and literature review. Springerplus 2013;2:142. [CrossRef]

8. Basavaraj A, Kadam M, Kadam DB. Primary Maxillary Sinus Plasmablastic Lymphoma in HIV/AIDS. J Assoc Physicians India 2016;64:71-2.

9. Kim JE, Kim YA, Kim WY, Kim CW, Ko YH, Lee GK, et al. Human immunodeficiency virus-negative plasmablastic lymphoma in Korea. Leuk Lymphoma 2009;50:582-7. [CrossRef]

10. Choi SY, Cho YA, Hong SD, Lee JI, Hong SP, Yoon HJ. Plasmablastic lymphoma of the oral cavity in a human immunodeficiency virusnegative patient: a case report with literature review. Oral Surg Oral
Med Oral Pathol Oral Radiol 2014;117:e115-20. [CrossRef]

11. Hatanaka K, Nakamura N, Kishimoto K, Sugino K, Uekusa T. Plasmablastic lymphoma of the cecum: report of a case with cytologic findings. Diagn Cytopathol 2011;39:297-300. [CrossRef]

12. Cao C, Liu T, Zhu H, Wang L, Kai S, Xiang B. Bortezomib-contained chemotherapy and thalidomide combined with $\mathrm{CHOP}(\mathrm{Cy}$ clophosphamide, Doxorubicin, Vincristine, and Prednisone) play promising roles in plasmablastic lymphoma: a case report and literature review. Clin Lymphoma Myeloma Leuk 2014;14:e145-50.

13. Lin L, Zhang X, Dong M, Li L, Wang X, Zhang L, et al. Human immunodeficiency virus-negative plasmablastic lymphoma: A case report and literature review. Medicine (Baltimore) 2017;96:e6171.

14. Reagan L, Castillo JJ, Reagan JL. Plasmablastic lymphoma: a systematic review. ScientificWorldJournal 2011;11:687-96. [CrossRef]

\section{Orbital Komplikasyona Yol Açan Maksiller Sinüs Plazmablastik Lenfoması}

Nadir görülen plazmablastik lenfoma (PBL) AIDS ile ilişkili, oral mukoza yerleşimli, kötü prognozlu, diffüz büyük B hücreli lenfoma varyantı olarak kabul edilmektedir. Plazmablastik lenfomanın henüz tedavisinde standart bir protokol olmaması, olgu bildirimi ve çalışmalar halinde yapılan az sayıda HIV negatif olguların tedavisi olgu bazlı olarak yapılmakta ve paylaşılmaktadır. Bu yazıda maksiller sinüs kaynaklı ve orbitaya yayılmış olan PBL'li 60 yaşında erkek, HIV negatif ve immün kompetan hastamıza uyguladığımız tedavi ve takip süreci literatür bilgileri eşliğinde sunulmuştur.

Anahtar Sözcükler: Burun tıkanıklığı; HIV negatif; komplikasyon; maksiler sinüs; orbita; plazmablastik lenfoma. 